Pollay Research

WORKING PAPERS

Country Operatlons

Technical Department

Latin America and the Caribbean

The World Bank

November 1992

WPS 1028

\title{
Socioeconomic and Ethnic Determinants of Grade Repetition in Bolivia and Guatemala
}

\author{
Harry Anthony Patrinos \\ and \\ George Psacharopoulos
}

Children from less wealthy households and children of indigenous origins are more likely to repeat a grade, so targeted interventions could be directed at the poor and could have an indigenous component, such as bilingual education.

Policy Research Working Papers disseminate the findings of work in progress and encourage the exchange of ideas among Bank staff and Policy Research Working Papers disseminate the findings of work in progress and encourage the exchange of ideas among Bank staff and only theirviews, and should be used and cited accordingly. The findings, interpretations, and conclusions are the author' own. They should not be attributed to the World Bank, its Board of Directors, its management, or any of its member countries. 


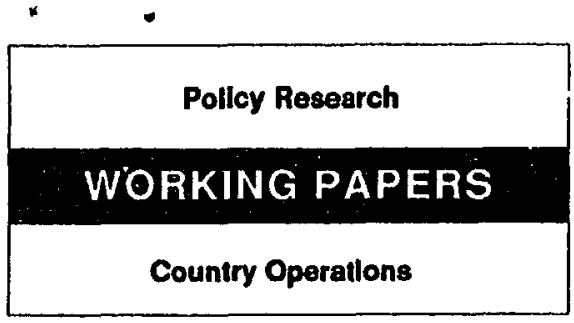

WPS 1028

This paper - a product of the Latin America and the Caribbean Technical Department - is part of a larger effort to document poverty conditions in the region. Copies of the paper are available free from the World Bank, 1818 H Street NW, Washington, DC 20433. Please contact Liliana Longo, room I4-187, extension 39244 (November 1992, 26 pages).

After reviewing the literature on repetition (students repeating grades in school) in developing countries, Patrinos and Psacharopoulos examine factors related to repetition in Bolivia and Guatemala. They develop a model to estimate the incidence and determinants of repetition. They use multivariate logistic regression analysis to estimate the determinants of repetition, using the results in simulations to determine probabilities of who is more likely to repeat.

Their empirical analysis shows that certain populations are more likely to repeat a grade: children from less wealthy households and children of indigenous origins. This suggests that any targeting activities could be directed to the poor and could have an indigenous component, such as bilingual education.

The Policy Research Working Paper Series disseminates the findings of work under way in the Bank. An objective of the series is to get these findings out quickly, even if presentations are less than fully polished. The findings, interpretations, and conclusions in these papers do not necessarily represent official Bank policy. 
SOCIOECONOMIC AND ETHNIC DETERMINANTS OF GRADE REPETITION

\author{
IN BOLIVIA AND GUATEMALA
}

$$
\text { by }
$$

Harry Anthony Patrinos and George Psacharopoulos

The World Bank

Washington, DC 20433 
Table of Contents

I. Introduction 1

II. Literature Review 1

III. A Bird's Eye View of Repetition in Latin America 3

IV. An Empirical Investigation 5

Descriptive Statistics 9

Multivariate Analysis 13

$\begin{array}{ll}\text { V. Conclusion } & 18\end{array}$

$\begin{array}{ll}\text { References } & 19\end{array}$

Annex 1 Mean Sample Characteristics, Bolivia 1989

Annex 2 Zero-Order Correlation Matrix $\quad 24$

Annex 3 Logistic Regression Results: The Determinants of
Repetition in Bolivia

* The authors wish to thank Haeduck Lee and Hongyu Yang for providing assistance during the various stages of preparing this paper. 


\section{Introduction}

School dropout and grade repetition are among the most serious problems plaguing educational systems around the world today. This problem is especially pronounced in Latin America and the Caribbean, the region with the highest incidence of repetition and dropout in the world (see Unesco 1991). Nearly half the children who enroll in the first grade never complete the fourth grade. Latin America leads the developing world in the percentage of repeaters in primary education. On average, about 29 percent of all primary students are repeaters each year; and 42 percent are repeating the first grade (Schiefelbein 1992). Clearly, repetition is the key issue in Latin American primary education, both for improving overall efficiency and reaching suitable levels of quality (Schiefelbein 1989). Repetition also acts as a signal that something is wrong, that achievement is inadequate, that the quality of schooling is low, or that learning disabilities brought from a deprived learning environment are present.

School repetition and school dropout are closely linked, the one often leading to the other. They can be attributed to the supply side, i.e. the offering of low quality instruction, or to the demand side, i.e. families needing child labor for agricultural production and hence withdrawing their children from school, or forcing them to repeat because they have not learned the material during the school year because of work-related distractions.

It is important to note that the reduction of repetition and dropout are not ends in themselves. Regarding repetition, learning is the issue. If a student learns more by repeating a grade, repetition is not a problem (see Psacharopoulos, Rojas and Vélez 1992), except in terms of efficiency costs if alternatives exist. However, it is a problem if repetition becomes perennial, leading to dropout before a child attains literacy. At some stage, a child must "drop out" of school, e.g. at the end of the primary, secondary or higher education cycle. But if dropout occurs before a child finishes the compulsory level of education, presumably also missing literacy for life, then dropping out of school is a very serious problem.

In this paper we first review the literature on repetition in developing countries and then examine a series of factors that relate to repetition based on household survey data for both Bolivia and Guatemala. We then proceed to estimate the determinants of repetition using a series of household demographic and ethnic variables. Results from the analysis are used to simulate the probabilities of repetition against particular characteristics.

\section{Literature Review}

The high levels of repetition and drop out at the primary schooling levels prevent the realization of universal primary education in many developing countries (Davico 1990; Schiefelbein 1989). Repeaters reduce the enrolment capacity of their class, thus preventing other children from being admitted. Repeaters also cause overcrowding, which raises school costs (Unesco 1984). Many authors have found that the major obstacle is the first grade (see, for example, Davico 1990; Schiefelbein 1992). Repeating the first grade often leads to more repetition, which is followed by eventual drop out, often resulting in illiteracy for life. 
Davico (1590) found that poor teachers and inadequate support to poor children are to blame for the high rates of repetition and drop out in Brazil. It is often the case that the poorest teachers are to be found in the first grade. There is also evidence of discrimination against students from disadvantaged backgrounds, and a belief among teachers that poor students cannot learn. The teaching method reinforces such attitudes, leading to high rates of repetition and drop out for those from disadvantaged backgrounds. Schiefelbein also finds that repetition is especially severe among the most deprived; that is, those whose parents have the lowest levels of education and income are more likely to repeat a grade (Schiefelbein 1992: 7). Recent research for Uruguay has found that repetition decreases significantly as the level of the parents' education income increases (Schiefelbein 1992: 6).

Repetition rates are also high among those living in rural, isolated areas, and among indigenous peoples and non-whites. It has been found that the repetition rate is twice the national average in Malleco province in Chile, which has the highest proportion of indigenous people in the country (Schiefelbein 1992). Significant differences by gender have not been detected, and although girls in general do better than boys, gender differences have been diminishing over time (Schiefelbein 1992: 8). Schiefelbein (1992, 1989, 1975) adds some further explanatory factors, such as children with learning disabilities, "age hetercgeneity" in the classroom (see below), language and, in some cases, the lack of bilingual education.

Psacharopoulos and Yang (1991), in their study of educational attainment in Venezuela, also examined the problem of repetition. Using a 1987 sample of school children aged 10 to 18 years, they found that grade repetition was associated with urban areas (negative) and with being male (positive). They also established that family background (father's education) has a significant effect on lowering the repetition rate.

Regarding the determinants of grade repetition, Schwille et al. (1991) presented a detailed causal model to explain grade repetition. Three main categories were put forward, including: student characteristics, such as gender, ethnicity, family influences, place of residence, age, prior repetition experience, aptitudes, and perceived opportunities for work/employment; national policies regarding language, repetition, secondary school entrance, other access and selection policies, and the quality of instruction; and school characteristics, such as school management practices, coverage of syllabus, quality of instruction, compliance with national policies, and the capacity of the school relative to the number of non-repeaters. All this is hypothesized to cause repetition, which in turn affects student learning, student motivation, student self-esteem, the examination success rate, the enrolment rate, the dropout rate, and the mean time required to produce graduates.

The demand for child labor, whether paid or unpaid, affects schooling, often causing grade repetition. This relationship was examined by Bowman and Goldblatt (1984), who found that the demand for the productive contributions of children to the household economy are closely associated with "overage" and the proportions of youth who do not complete even four years of primary schooling (Bowman and Goldblatt 1984). 
Using a unique follow-up data set for Northeast Brazil, Gomes-Neto and Hanushek (1991) examine the causes and effects of grade repetition. They find that student achievement levels are very important, as is the availability of advanced grades. Jamison (1978) examined the determinants, among other things, of student failure and repetition in Nicaragua. Through an evaluation of the Radio Mathematics Project, and using maximum likelihood methods, he found that males are less likely to fail, that the number of times repeated has negative impact on failing during the current year, and that student achievement on test score are significant factors.

The costs of repetition are very high for a developing country. Estimates for Brazil show that the cost of repetition represents an amount equivalent to the entire federal government contribution to first level schooling (World Bank 1986). Policies to reduce repetition and dropout are advocated for the more efficient use of education resources. Cuadra and Fredriksen (1992) estimated efficiency gains associated with reducing repetition and dropout through a simulation exercise. They found that reductions in repetition and dropout rates would result in more students cumpleting the basic cycle of education at a lower input per graduate. Less repetition frees places and lowers the cost of graduating a cohort, while reduced dropout results in more students completing the cycle. Furthermore, less repetition may mean less dropout as the foregone earnings associated with schooling, which are greater when repetition is higher, decrease as the rate of repetition falls.

High levels of grade repetition do not only have cost and efficiency implications, but also affect the foregone eamings associated with attending school, outcomes, and the returns to education. It has been found that repetition rates affect the rate of return to education. Assuming it takes on average two extra years to complete the basic education cycle, and more for those froiri lower socioeconomic backgrounds, the returns to schooling are found to drop significsitly in Brazil, from 13 percent to 8 percent, after repetition is factored into the calculations (Jallade 1977). Also, Behrman and Deolalikar (1991), using Indonesian data, find that failure to account for repetition and drop out leads one to overestimate the returns to schooling.

\section{A Bird's Eye View of Repetition in Latin America}

Table 1 presents key information on primary schooling in Latin America, as well as conservative estimates of the indigenous population in some countries. While many children do not start school on time - according to the official primary school entry age -, most do, however, eventually enroll. Primary school coverage is complete in the Anglophone Caribbean region and Mexico, as well as for a number of Central and South American nations. The lowest levels of primary school coverage occur in Haiti, Guatemala, El Salvador, the Dominican Republic, and Nicaragua. 
Table 1. School Acces, Repetition, Grades Attained, and Indigenous Population in Latin America and the Caribbean

\begin{tabular}{lllll}
\hline Sub-region/ & School Accoss (\%) & Repetition & Years in & Grades Indigenous \\
Country & On time Ever & $(\%)$ & Primary Attained & $(\%)$
\end{tabular}

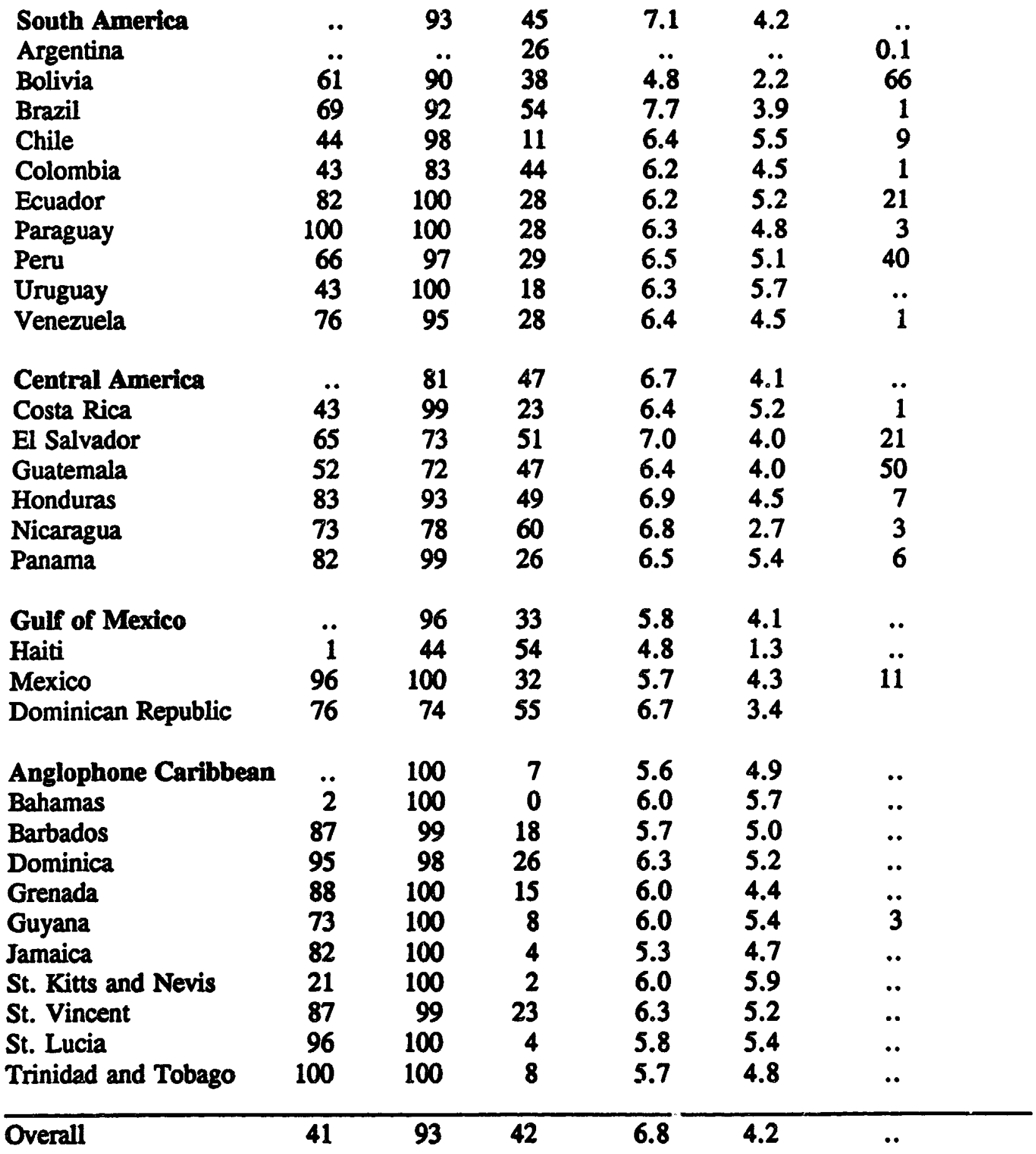


The rate of primary schoul coverage, however, has little relation to the rate of grade repetition in a country. Repeition rates at the primary level are very high, especially in South and Cential America. The rate of repetition, for instance, is over 50 percent in Brazil, and 60 percent in Nicaragua. The lowest rates of repec " "on occur in the Anglophone Caribbean.

In addition to very high repetition rates, primary schooling in most Latin American countries is inefficient. It takes, on average, seven years to complete four grades of primary schooling in South America. This means that one-and-one-half years of schooling are required to complete one grade at the primary level. In Brazil and Haiti, the differential between years of schooling and grades attained is even greater. This inefficiency occurs at a high level in Nicaragua, El Salvador, the Dominican Republic, Bolivia, and Guatemala. The difference between years of schooling and grades attained is negligible in most Caribbean countries.

Another feature of Table 1 is that it provides estimates of the indigenous population expressed as a percent of the total population for countries where this is relevant and the data was available. Several Latin American countries have sizable indigenous populations, the biggest being in Bolivia and Guatemala, where, according to most estimates, they constitute the majority of the population.

In many countries, due to a variety of factors, including language, lack of provision of social services, geographical location, and discrimination (see Kelley 1988; Stephen and Wearne 1984), being an indigenous person is associated with, among other things, extreme poverty and illiteracy. This is especially the case in rural, isolated areas, which places children in an extreme disadvantage. In rural Peru, for instance, where the majority of the population is indigenous, it has been found that 70 percent of Quechua-speaking prople over the age of five have never received any schooling, relative to only $\mathbf{4 0}$ percent of rural non-indigenous Peruvians (Hernandez 1988: 126).

\section{An Empirical Investigation}

In this paper we focus on children attending the primary level, aged less than 15 years. The reason for concentrating on primary schooling is that repetition is less of a problem at the secondary or tertiary levels. Also, since we do not have matching data on learning, we focus on household demographic, wealth and other demand factors in determining repetition. We also control for ethnicity by including indigenous identity as an independent variable in the analysis. For this reason we concentrate on the two Latin American countries with the highest proportion of indigenous peoples in their populations, Bolivia and Guatemala.

The data from Bolivia used in this analysis come from the 1989 Encuesta Integrada de Hogares (EIH) conducted by the Instituto Nacional de Estadistica. The survey covers only urban areas with populations over 10,000. Our analysis is limited to 5,614 enrolled primary school children between the ages of 7 and 14 who are still in school. For Guatemala, the data come from the Encuesta Nacional Socio-Demografica (ENSD), conducted in 1989 by the 
Instituto Nacional de Estadtstica. The survey covers about 11,000 households in all parts of the couniry. Our analysis is limited to 2,974 enrolled primary school children between the ages of 10 and 14.

The key dependent variable among the two groups of primary school children is REPEATER, or "overage", or "ageigrade distortion." A repeater is a student whose age is above the normal for the grade he/she just completed or is currently attending. Using a variable called schooling-for-age (SAGE) (see Pacharopoulos and Yang 1991), we assess the progress of a child in the school system and estimate repetition, or "overage". Using the formula:

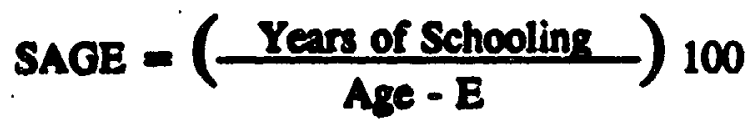

where E represents the usual school entry age in the country, age six in Bolivia, seven in Guatemala. We consider all those with a score under 100 as being below normal progress in the school system because of grade repetition or late entry.

However, as this measure of repetition may be capturing late entrants, it can be described more as a measure of "age-grade distortion," or "overage." Schiefelbein (1992: 31) noted that 60 percent of children in Bolivia enter school on time, that is, at age six; first grade repetition is 38.4 percent. The sample we are using, however, is urban only; therefore, late entrants may be fewer. Moreover, our method does not overestimate repetition - it underestimates it. According to our model, only 16.8 percent of Bolivian school children are estimated to be first igrade repeaters.

The Guatemalan alueation system, however, is characterized by high rates of failure at all grade levels, accompanied by repeating. While 52 percent of children enroll on time, more than 70 percent of rural stulents are older than the expected age for their grade, compared to 50 percent in urban areas. Sill, only 72 percent of Guatemalans ever enroll; and the rate of repetition is 47 percent (Schiefelbein 1992), although higher in rural areas. Our method gives a much higher rate, but it should be noted that this has much to do with the fact that the Guatemalan sample consists of children are already overaged; the sample is limited to those ten years of age and older (the Guatemalan survey did not collect information on those under ten years of age). Also, our sample, however, includes students between the ages of 7 and 14 (10 and 14 in Guatemala), in all primary school grades, so that a number of "late entrants" will have dropped out, and will consequently not be included in our study.

An important characteristic of the Latin American primary school, as well as a factor determining repetition, is the presence of children of various ages in the same grade, some of whom are themselves repeaters (Schiefelbein 1992: 10). Estimates of the "overaged" in primary schools in Latin America and the Caribbean range from 43 percent in Brazil, 34 percent in the rest of South America, and 32 percent in Central America (32 percent), to just 11 percent in the Anglophone Caribbean (OAS 1992). In general, age/grade distortion is much greater ili rural 
areas. In Peru, over 90 percent of urban children are in school by age six, while the same can be said for only 57 percent of rural children (Mon and Moock 1991).

Bowman and Goldblatt (1984) examined the phenomenon of "overage" in Mexican primary schools. They found that overage and low family incomes are strongly related, and that "low incomes (low ability to pay) had more serious negative efiects on the schooling of girls than of boys." A particularly interesting and useful finding was that overage in the first grade, and overage in primary school in ceneral, are not the same thing; in fact, they are negatively correlated. Early grade repetition is strongly associated with drop out, while being overage in primary school (but not first grade) indicates school progress.

On the question of whether "overage" more heavily represents repetition or late entry, the answer is unclear and although there are competing theories, the evidence to date has not been conclusive. Enrolling in primary school on time has been found to be positively associated with family wealth and parents' schooling, and negatively associated with school costs in Ptr:1 (Ilon and Moock 1991). This means that for a variety of reasons it is the poor who are moie likely to enroll late, repeat grades and eventually drop out of school, given the relationship between overage, repetition, and dropout. Other reasons put forward for delayed enrollment in primary school include borrowing constraints, the opportunity cost of child labour, a lack of school places, and malnutrition (Glewwe and Jacoby 1992).

Some researchers, however, argue that the principal cause of age/grade distortion is grade repetition, and not late entrance (Verhine and de Melo 1988: 564). Schiefelbein (1992, 1975) hypothesizes that "age heterogeneity" is also a cause of repetition. This is because of the effect on learning and teaching methods in the classroom when there are children of various ages in the same grade. It is "difficult for the teacher to generate learning experiences of interest for the whole range of ages" (Schiefelbein 1992: 10). He goes on to report that "for the most part, age heterogeneity corresponds to overage resulting from repetition." Repetition generates age heterogeneity, which causes problems in the classroom for non-repeaters as well, as teaching methods change in an attempt to accommodate children of various ages in the same grade. Repetition is expected to be greater, the higher the level of age heterogeneity in a given classroom. In other words, present repetition leads to a cycle of increased repetition. All this shows that even the late entrants in our sample of "repeaters" has consequences, for themselves, as well as for the students in a normal schooling trajectory. The evidence and theory, therefore, tentatively point to the conclusion that overage and repetition may be the same thing in Latin America.

The independent variables to be considered in the empirical analysis are as follows:

AGE, the student's age: ranging from 7 to 14 in Bolivia, and 10 to 14 in Guatemala

MALE, the gender variable (0-1 dummy)

INDIG, whether the student is indigenous (0-1 dummy) 
REGION, residence in one of Bolivia's eight Departamentos, or urban/rural in Guatemala

PRIVATE, attendance at a private school (0-1 dummy), Bolivia only

SM, mother's years of schooling

YFAM, family income

MALEHHD, male household head (0-1 dummy)

OCCHHD, occupation of household head (5 major categories in Bolivia, 4 in Guatemala)

NSIBS, the number of brothers and sisters

NROOMS, number of rooms in the household

KITCHEN, the presence of a kitchen in the houseinold (0-1 dummy)

RUNWATER, the presence of running water in the household (0-1 dummy)

The means and standard deviations of the sample variables are presented in Annex 1.

We are interested in the effect of the above independent variables on repetition. The model to be estimated is a regression with a dichotomous dependent variable, REPEATER, defined as above. For this reason, logistic regression analysis will be used. The model is as follows:

\section{REPEATER $=f(A G E, M A L E, I N D I G, R E G I O N,(P R I V A T E$,$) SM, YFAM, MALEHHD,$ OCCHHD, SIBS, NROOMS, KITCHEN, RUNWATER)}

As mentioned above, the aim of this empirical study is to explain the determinants of repetition with household charaiteristics, controlling for ethnicity. It is expected that family income and indicators of relative wealth (such as KITCHEN, RUNWATER, NROOMS) will be negatively associated with repetition. Positive associations with repetition are expected for the variables controlling for indigenous origins and numbers of brothers and sisters. As parentai schooling is considered important, it is expected that mother's schooling will be negatively associated with repetition. Mother's schooling was chosen over father's schooling as a control variable because at early ages it is the mother who spends more time with the child. Nevertheless, the presence of a male household head is also controlled for, the hypothesis being that female-headed households are likely to be less wealthy, consequently less able to provide the proper home environment for the child to ensure success at school. It is, therefore, expected that the presence of a male household head will be negatively as sciated with repetition. We also control for the housetiold head's occupation, regardless of gender. Region of residence is expected to show great differences in repetition rates, reflecting the quality and accessibility of 
schooling in different areas, as well as relative wealth. For Bolivia, being an urban-only sample, we control for Departamento of residence. For Guatemala, we use the rural/urban divide, ana judging from previous analyses, we expect the rate of repetition to be considerably higher in rural areas, for reasons such as inferior quality schools. Age, another control variable, is expected to be positively assuciated with repetition because the longer one remains in primary school, the more likely it is they have repeated a grade.

\section{Descriptive Statistics}

The mean sample characteristics for repetition by discrete independent variables are presented in Table 2. The mean repetition rate increases with age, as those students that continue in the system accumulate repeated grades.

Girls have a slightly higher rate of repetition than boys. This aggregate result is somewhat surprising since, accord:ig to other accounts, boys have higher rates of repetition in most Latin American countries (Schiefelbein 1992).

Indigenous ethnicity and repetition are highly correlated. A primary school student of indigenous origin is almost twice as likely to be a repeater relative to a non-indigenous child in Bolivia, while the rate of repetition for indigenous children in Guatemaia is almost 90 percent.

The rate of repetition varies by region, or Departamento in Bolivia, of residence. It ranges from only 16 percent in Chuquisaca in southern Bolivia, to 37 percent in Beni, in the north. The Bolivian sample refers only to the urban sector. In Guatemala, however, where we possess information on both the rural and the urban sectors, great diversities are made apparent. While the overall rate of repetition is only 55 percent in urban areas, it is over 80 percent in rural areas.

For Bolivia, the type of school attended is known. For those attending public schools, the rate of repetition is over 29 percent; it is a mere 8.7 percent for those in private schools.

Parent's schooling and family income also affect repetition rates. In Bolivia, if the father has less than a primary education, the aggregate repetition ra is is over 34 percent; however, for those whose mothers have a complete secondary education or more, the repetition rate on average is less than 9 percent. In Guatemala, for those whose mother (father) has incomplete primary schooling, the rate of repetition is $\mathbf{7 4}$ percent; for those whose mother (father) has a complete secondary education, the rate of repetition is only around 30 percent. The rate of repetition also varies according to family income yuintile, ranging from almost 29 percent for those in the bottom 20 percent, to less than 17 percent for those in the top 20 percent in Bolivia. In Guatemala, repetition varies from 84 percent at the bottom of the income distribution, to 50 percent at the top.

The occupation of the household head also matters. In Bolivia, the rate of repetition is lower for children from households where the household head is an employer (12 percent), as 
opposed to a laborer (35 percent). In Guatemala, the lowest rate of repetition registered is for those where the household head is a public sector employee (49 percent), and the highest is for self-employed household heads (78 percent).

Repetition is found to be less for school children in Bolivia in households where the household head is male, while in Guatemala, surprisingly, repetition is lower if the household head is female. The recuons for this anomaly are unclear.

Several other household variables are used in the analysis. In general, the fewer brothers and sisters one has, the more rooms in the house, the presence of a kitchen and running water are all associated with lower rates of repetition in both countries. 
Table 2. Mean Repetition Ratea by Selected Sample Charecteristics (\%)

\begin{tabular}{|c|c|c|}
\hline Characteristic & Bolivia & Guatemala \\
\hline $\begin{array}{c}\text { Age } \\
8 \\
9 \\
10 \\
11 \\
12 \\
13 \\
14\end{array}$ & $\begin{array}{l}14.8 \\
22.8 \\
25.6 \\
28.2 \\
30.6 \\
37.4 \\
49.7\end{array}$ & $\begin{array}{r}60.7 \\
65.2 \\
70.2 \\
78.9 \\
100.0\end{array}$ \\
\hline $\begin{array}{l}\text { Gender } \\
\text { Female } \\
\text { Male }\end{array}$ & $\begin{array}{l}25.5 \\
24.1\end{array}$ & $\begin{array}{l}71.8 \\
70.6\end{array}$ \\
\hline $\begin{array}{l}\text { Ethnicity } \\
\text { non-Indigenous } \\
\text { Indigenous }\end{array}$ & $\begin{array}{l}22.6 \\
40.8\end{array}$ & $\begin{array}{l}64.3 \\
87.6\end{array}$ \\
\hline $\begin{array}{l}\text { Region/Departamento } \\
\text { Chuquisaca } \\
\text { Cochabamba } \\
\text { Oruro } \\
\text { Sants Cruz } \\
\text { Tarija } \\
\text { Potosi } \\
\text { La Paz } \\
\text { Beni }\end{array}$ & $\begin{array}{l}15.8 \\
17.8 \\
22.4 \\
22.4 \\
23.5 \\
26.9 \\
29.5 \\
36.8\end{array}$ & \\
\hline $\begin{array}{l}\text { Rural } \\
\text { Urban }\end{array}$ & & $\begin{array}{l}83.0 \\
55.0\end{array}$ \\
\hline $\begin{array}{l}\text { Type of School } \\
\text { Public } \\
\text { Private }\end{array}$ & $\begin{array}{r}29.4 \\
8.7\end{array}$ & \\
\hline $\begin{array}{l}\text { Mother's Schooling } \\
\text { Incomplete Primary } \\
\text { Complete Primary + } \\
\text { Complete Secondary + }\end{array}$ & $\begin{array}{r}29.9 \\
18.5 \\
8.6\end{array}$ & $\begin{array}{l}74.3 \\
46.0 \\
31.4\end{array}$ \\
\hline
\end{tabular}


Table 2 (Cont'd)

\begin{tabular}{|c|c|c|}
\hline Characteristic & Bolivia & Guatemala \\
\hline $\begin{array}{l}\text { Father's Schooling } \\
\text { Incomplete Primary } \\
\text { Complete Primary + } \\
\text { Complete Secondary + }\end{array}$ & $\begin{array}{l}34.4 \\
23.2 \\
11.5\end{array}$ & $\begin{array}{l}74.5 \\
55.2 \\
29.8\end{array}$ \\
\hline $\begin{array}{l}\text { Family Income Quintile } \\
\text { Bottom } 20 \\
\text { Next } 20 \\
\text { Middle } 20 \\
\text { Next } 20 \\
\text { Top } 20\end{array}$ & $\begin{array}{l}28.5 \\
28.8 \\
26.5 \\
23.4 \\
16.6\end{array}$ & $\begin{array}{l}84.1 \\
78.8 \\
74.0 \\
66.3 \\
49.9\end{array}$ \\
\hline $\begin{array}{l}\text { Household Head Gender } \\
\text { Female } \\
\text { Male }\end{array}$ & $\begin{array}{l}32.7 \\
24.2\end{array}$ & $\begin{array}{l}63.0 \\
72.4\end{array}$ \\
\hline $\begin{array}{l}\text { Household Head Occupati } \\
\text { Employer } \\
\text { Employee } \\
\text { Self Employed } \\
\text { Laborer } \\
\text { Public Sector Employee } \\
\text { Private Sector Employee }\end{array}$ & $\begin{array}{l}12.2 \\
18.6 \\
27.6 \\
35.1\end{array}$ & $\begin{array}{l}61.3 \\
77.8 \\
49.2 \\
72.5\end{array}$ \\
\hline $\begin{array}{l}\text { Siblings } \\
1 \text { to } 2 \\
3 \text { to } 4 \\
5+\end{array}$ & $\begin{array}{l}18.0 \\
21.2 \\
33.3\end{array}$ & $\begin{array}{l}65.1 \\
75.6 \\
80.5\end{array}$ \\
\hline $\begin{array}{l}\text { Number of Rooms } \\
1 \\
2 \\
3 \\
4 \\
5 \text { or more }\end{array}$ & $\begin{array}{l}36.6 \\
27.3 \\
25.1 \\
18.4 \\
13.1\end{array}$ & $\begin{array}{l}86.7 \\
78.7 \\
71.9 \\
64.0 \\
42.3\end{array}$ \\
\hline $\begin{array}{l}\text { Kitchen } \\
\text { No } \\
\text { Yes }\end{array}$ & $\begin{array}{l}31.6 \\
23.0\end{array}$ & $\begin{array}{l}76.1 \\
64.6\end{array}$ \\
\hline $\begin{array}{l}\text { Running Water } \\
\text { No } \\
\text { Yes }\end{array}$ & $\begin{array}{l}29.9 \\
18.7\end{array}$ & $\begin{array}{l}80.7 \\
62.7\end{array}$ \\
\hline Overall & 24.8 & 71.2 \\
\hline
\end{tabular}


Multivariate analysis

The results of a multivariate model controlling for the factors that simultaneously determine grade repetition appear in Annex 3. Since the "primary school repeater" is a 0-1 limited dependent variable, a logit model was fitted. The model expresses the probability $(P)$ of someone being a primary school repeater, as a function of various characteristics $(\mathrm{X})$, such as age, indigenous origin, gender, and so on.

$$
P=\frac{1}{1+e^{-\sum \beta_{1} x_{1}}}
$$

The reported coefficients in the last column of Annex 3 are partial derivatives indicating the change in the probability of repeating a grade in primary education relative to a unit change in one of the independent variables,

$$
\frac{\partial P}{\partial X_{1}}=\beta_{1} P(1-P)
$$

where $P$ refers to the dependent variable-probability of the event, beta to the logit coefficient and $\mathbf{X}$ to the string of independent variables used in the regression. For example, every extra year of mother's education decreases the probability of the child repeating a school grade by more than six percentage points in Guatemala, relative to a mean repetition rate of 77.9 percent.

The results of the logit analysis are used to estimate probabilities of repetition against selected sample characteristics. Probabilities of repetition are simulated by varying one characteristic at a time, while holding other variables constant at their mean levels. The results of the simulations are presented in Table 3. Highlights are given in Figure 1.

As expected, the variables age and indigenous origin have a large, positive, and significant effect on being a repeater. The older the child is, the greater the probability of being a repeater; from 12 percent at age 8 , to over 52 percent at age 14 in Bolivia, and from 55 percent at age 10, to 94 percent at age 14 in Guatemala. A child of indigenous origin has at least a five percent greater probability of being a repeater than does a non-indigenous child in Bolivia, and a more than nine percent chance of being a repeater in Guatemala. 
Table 3. Predicted Probability of Repetition by Selected Sample Characteristics (\%)

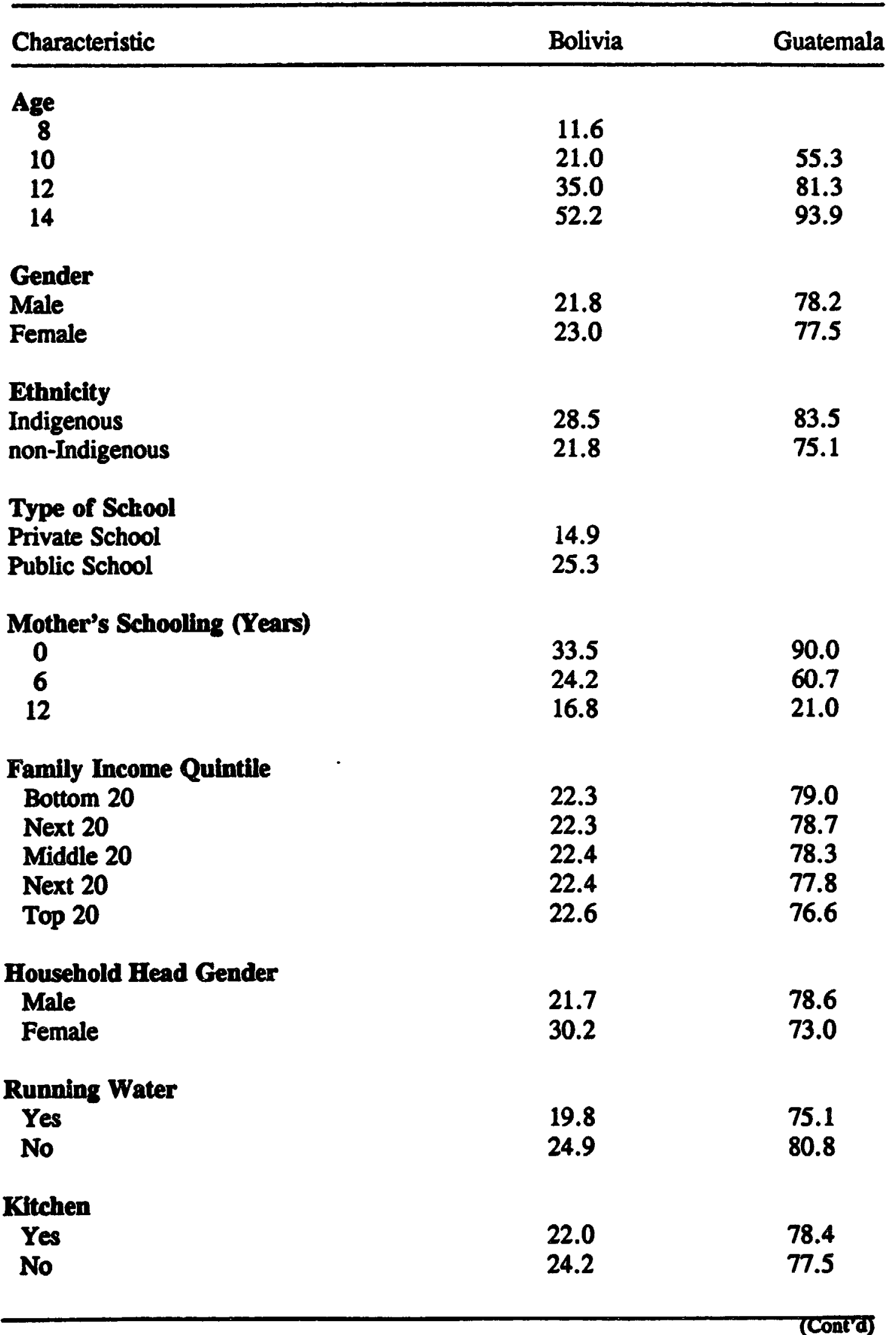


Table 3 (Cont'd)

\begin{tabular}{|c|c|c|}
\hline Characteristic & Bolivia & Guatemala \\
\hline \multicolumn{3}{|l|}{ Household Head Occupation } \\
\hline Laborer & 24.3 & \\
\hline Employee & 18.8 & \\
\hline Self Employed & 25.1 & 78.3 \\
\hline Employer & 13.1 & $\mathbf{7 8 . 0}$ \\
\hline Private Sector Employee & & 79.3 \\
\hline Public Sector Employee & & 70.2 \\
\hline \multicolumn{3}{|l|}{ Region/Departamento } \\
\hline Chuquisaca & 12.8 & \\
\hline Cochabamba & 14.9 & \\
\hline Oruro & 16.0 & \\
\hline Potosi & 18.3 & \\
\hline Tarija & 18.5 & \\
\hline Santa Cruz & 18.1 & \\
\hline Beni & 31.4 & \\
\hline Urban & & 70.1 \\
\hline Rural & & 82.6 \\
\hline \multicolumn{3}{|l|}{ Number of Siblings } \\
\hline 0 & 16.0 & 62.4 \\
\hline 2 & 19.0 & 74.0 \\
\hline 4 & 22.4 & 83.0 \\
\hline 6 & 26.2 & 89.3 \\
\hline \multicolumn{3}{|l|}{ Number of Rooms } \\
\hline 1 & 27.7 & 84.2 \\
\hline 2 & 25.1 & 81.1 \\
\hline 3 & 22.4 & 77.5 \\
\hline 4 & 20.4 & 73.6 \\
\hline 5 & 18.4 & 69.2 \\
\hline 6 & 16.5 & 64.4 \\
\hline Repeater (overall probability) & 24.2 & 77.9 \\
\hline
\end{tabular}


The findings associated with indigenous people have been verified in previous analyses, especially for Guatemala. Rojas (1991) found that being "non-white" significantly affects educational attainment in Guatemala. Carvajal and Morris (1989/1990), analyzing 1986 data from Guatemala's Programa Nacional de Educacion Bilingue (PRONEBI) from 297 communities and from a questionnaire administered to the same communities, found sizable differences among indigenous groups ${ }^{1}$ with respect to grade repetition and dropout, ranging from 30 to 46 percent repetition, and 6 to 16 percent drop out rates. The authors attempted to explain the differences with the use of community socioeconomic characteristics and differences among indigenous groups. It was found that bilingualism improves grade repetition and drop out rates, and that the opportunity cost of child labour should be taken into account when devising school schedules. In a country where more than 40 percent of the population begins school without knowledge of Spanish, there is a serious need for teachers with indigenous language knowledge. The promotion standards in Guatemala have been found to be unrealistic. It is usually necessary for first grade students to leam to read and write Spanish or else they repeat the grade; this, no doubt, is very difficult for those who do not know Spanish when they enter first grade. The Bilingual Education Project had a significant impact on promotion rates, more than nine percent higher for bilingual students relative to the control group in the first grade in 1983 (Townsend and Newman 1985).

Region of residence also has a significant and large impact on repetition rates. Departamento of residence in urban Bolivia showed great differences, as did rural/urban sector in Guatemala. The probability of repetition is considerably lower in urban Guatemala.

The number of brothers and sisters one has also has a positive and significant impact on being a repeater. The probability of being a repeater in Bolivia for those with no siblings is only 16 percent, while for those with 6 siblings the probability of repetition is over 26 percent. In Guatemala, this ranges from 62 to 89 percent.

Attendance in a private school has a very large, negative and significant impact on being a repeater in Bolivia. The difference between public and private school repetition probabilities is great, at only 14.9 percent for private school students, and over 25 percent for public school students. We do not have information on type of school attended for Guatemalan children.

In Bolivia, female headed households are associated with higher probabilities of repetition, compared with male headed households. The opposite relationship holds true in Guatemala, however, and the reasons are unclear at present. In addition, the probability of repetition was less for those Bolivian children where the household head was an employer, compared with the other occupational categories controlled for in the analysis. Mother's years of schooling also had a negative and significant impact on repetition, the probability of repetition in Bolivia declining from over 33 percent when the mother had no schooling, to less than 17 percent when the mother had 12 years of schooling. In Guatemala, the probability of repetition

${ }^{1}$ There are 25 different indigenous languages spoken in Guatemala (Carvajal and Morris 1989/1990). 

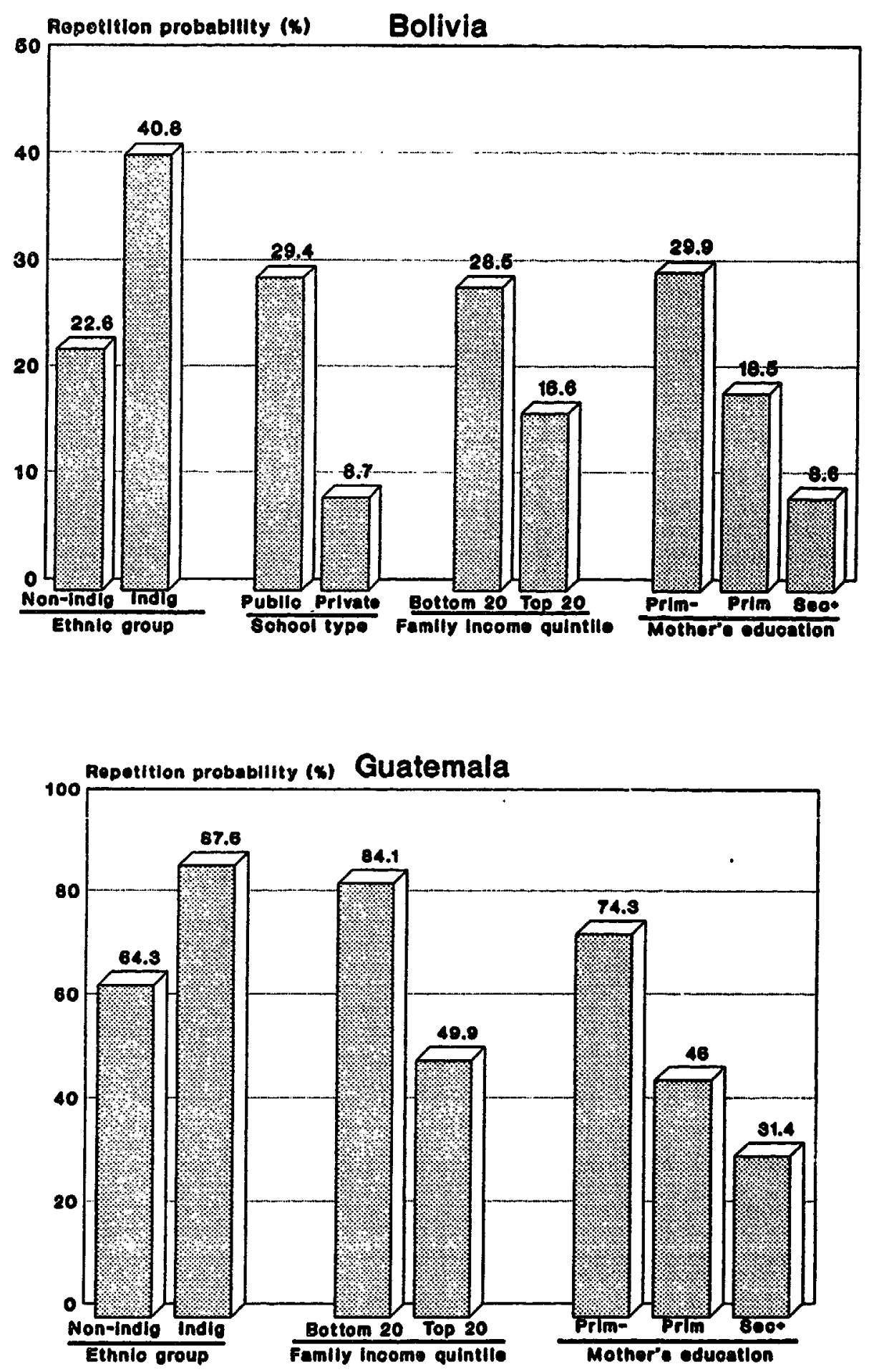

Eloure 1. Repetition Probabilities by Socio-economic Characteristics 
drops dramatically for those whose mother has 12 years of schooling (21 percent), from the high registered for those whose mother has no schooling ( 90 percent). Parental education was found to have a positive association with school attendance in Guatemala (Balderston 1989), where it was also found that the opportunity cost for child labour was negatively associated with school attendance. Child malnutrition, as measured by height, was also found to be significantly related to schooling (see Glewwe and Jacoby 1992 for a similar study on Ghana).

Interestingly, family income did not have much of an effect on repetition rates. The probability of repetition in both countries did not vary much among the five income categories presented in Table 3. This, however, shows that income is not a very good indicator of household wealth, this being reflected in the fact that other household wealth indicators did show significant and predicted differences in relation to repetition rates. For example, the presence of running water in the household was associated with a lower rate of repetition. Also, the more rooms in a house, the lower the rate of repetition, from 28 percent in a one room home, to 17 percent in a six room household in Bolivia, and from 84 percent (one room) to 64 percent (six rooms) in Guatemala.

\section{Conclusion}

An empirical investigation into the causes of grade repetition (or overage) in Bolivia and Guatemala, while limited to socioeconomic and household factors, led to the findings that certain populations are more likely to be affected. Children from less wealthy households are more likely to repeat grades. Students of indigenous origins also have higher probabilities of grade repetition, suggesting that any targeting activities should have an indigenous component. A very large difference in repetition rates was found between types of schools (in Bolivia), private versus public, favoring those students attending the private schools. While this may have much to do with the socioeconomic background of the students attending private schools, an investigation into the teaching and promotion practices of these schools is warranted.

One simple method of reducing repetition is to introduce mandatory promotion. This, however, ignores the fact that learning occurs through repetition, as is discussed by Gomes-Neto and Hanushek (1991). Continually high repetition rates, on the other hand, may also not be very efficient as they are associated with dropping out of school. The solution, therefore, rests in policies designed to get at repetition and overage by targeting the right population: the poor. Moreover, in countries such as Bolivia and Guaiemala, with large indigenous populations, the provision of bilingual education could be implemented quickly and extensively.

2 On bilingual education in Latin America, see: Amadio (1990), Lopez (1990), Lopez and d'Emilio (1992), Albo and d'Emilio (1990), Moya (1990), Varese (1990), Gurdian and Salamanca (1990), Zuniga (1990), Martinez (1990), and Cossio (1991). 


\section{REEERENCES}

Albo, X. and L. d'Emilio, 1990. "Indigenous Languages and Intereultural Bilingual Education in Bolivia." Prospects 20,3: 321-30.

Amadio, M. 1990. "Two Decades of Bilingual Education in Latin America (1970-90)." Prospects 20,3: 305-10.

Balderston, J.B. 1984. "Determinants of Children's School Participation." In J.B. Balderston et al. Malnourished Children of the Rural Poor. Boston: Aubum House Publishing Company.

Behrman, J.R. and A.B. Deolalikar. 1991. "School Repetition, Dropouts, and the Rates of Return to Schooling: The Case of Indonesia." Oxford Bulletin of Economics and Statistics 53,4: 467-480.

Berger, J. 1990. The Gaia Atlas of First Peoples. New York: Doubleday.

Bowman, M.J. and P. Goldblatt. 1984. "School Attainments in a Development Perspective: Transition Patterns in Mexico." Comparative Education Center, Department of Education, University of Chicago, Working Paper 84-6.

Carvajal, M.J. and F.K. Morris. 1989/1990. "Educacion Formal: ¿Vehiculo de Integracion Economica y Social del Indio Guatemalteco." Revista de la Integracion y el Desarrollo de Centroamerica 45-46: 95-110.

Cossio, C.Y. 1991. "The Implementation of Language Policy: The Case of Ecuador." Intemational Review of Education 37,1: 53-66.

Cuadra, E. and B. Fredriksen. 1992. "Scope for Efficiency Gains Resulting from Reduction in Repetition and Dropout: A Simulation Exercise." World Bank, Population and Human Resources Department, Education and Employment Division, Document No. PHREE/92/55.

Davico, M.I. 1990. "The Repeat and Drop-out Problem: A Study in Brazil on the Role of the Teacher." Prospects 20,1: 7-11.

Glewwe, P. and H. Jacoby. 1992. "An Economic Analysis of Delayed Primary School Enrollment and Childhood Malnutrition in a Low Income Country." Washington, D.C.: Population and Human Resources Department, The World Bank.

Gomes-Neto, J.B. and E.A. Hanushek. 1991. "The Causes and Effects of Grade Repetition: Evidence from Brazil." Rochester Center for Economic Research, Working Paper No. 295. 
Gurdian, G. and D. Salamanca. 1990. "Bilingual Education in Nicaragua." Prospects 20,3: 357-364.

Hernandez, I. 1988. "Identidad Indigena y Educacion." Desarrollo Economico 28,109: 121137.

Ilon, L. and P. Moock. 1991. "School Attributes, Household Characteristics, and Demand for Schooling: A Case Study of Rural Peru." International Review of Education 37,4: 429-452.

Jallade, J.-P. 1977. "Basic Education and Income Inequality in Brazil: The Long-Term View." World Bank Staff Working Paper No. 268.

Jamison, D.T. 1978. "Radio Education and Student Repetition in Nicaragua." In P. Suppes, B. Searle, and J. Friend, eds., The Radio Mathematics Project: Nicaragua 1976-197i. Stanford: Institute for Mathematical Studies in the Social Sciences, Stanford University.

Kelley, J. 1988. "Class Conflict or Ethnic Oppression? The Cost of Being Indian in Rural Bolivia." Rural Sociology 53,4: 399-420.

Lopez, L.E. 1990. "Development of Human Resources in and for Bilingual Intercultural Education in Latin America." Prospects 20,3: 311-320.

Lopez, L.E. and L. d'Emilio. 1992. "Bilingual Education Beyond National Frontiers. Bolivian-Peruvian Cooperation." The Major Project of Education in Latin America and the Caribbean Bulletin 27: 41-56.

Martinez, P.P. 1990. "Towards Standardization of $\mathrm{T}$ эnguage for Teaching in the Andean Countries." Prospects 20,3: 377-386.

Moya, R. 1990. "A Decade of Bilingual Education and Indigenous Participation in Ecuador." Prospects 20,3: 331-344.

Organizacion de los Estados Americanos. 1992. Niveles Educativos Basicos en America Latina y el Caribe: Situacion Actual y Perspectivas. Documentos de Trabajo del Proyecto Multinacional de Educacion Basica (PRODEBAS), 1.

Psacharopoulos, G. and H. Yang. 1991. "Educational Attainment among Venezuelan Youth: An Analysis of Its Determinants." International Journal of Educational Development 11,4: 289-294.

Psacharopoulos, G., C. Rojas, and E. Vélez. 1992. "Achievement Evaluation of Colombia's Escuela Nueva: Is Multigrade the Answer?", World Bank, Policy Working Papers No. 896. 
Rojas, E. 1991. "Factores que explican los niveles de escolaridad media de los hijos en Guatemala." Santiago: UNESCO-OREALC. Cited in Schiefelbein 1992.

Schiefelbein, E. 1992. "Repetition in Latin America's Primary Schools: Magnitudes, Causes, and Possible Solutions", The World Bank, LATHR (mimeo).

Schiefelbein, E. 1989. "Repetition: The Constraint for Reaching Universal Primary Education in Latin America." Bulletin: The Major Project in the Field of Education in the Latin American and Caribbean Region 18: 7-28.

Schiefelbein, E. 1975. "Repeating: An Overlooked Problem of Latin American Education." Comparative Education Review 19,3: 468-487.

Schwille, J. et al. 1991. "Is Grade Repetition Always Wasteful? New Data and Unanswered Questions." Bridges Research Report Series 7 (January).

Stephen, D. and P. Wearne. 1984. Central America's Indians with a summary by $\mathbf{R}$. Stavenhagen. London: Minority Rights Group.

Townsend, J. and B. Newman. 1985. "Bilingual Education Project in Guatemala: Preliminary Results on the Test of Principal Hypothesis during 1983." INCAP.

Unesco, Office of Statistics. 1984. "Wastage in Primary Education from 1970 to 1980." Prospects 14, 3: 347-367.

Varese, S. 1990. "Challenges and Prospects for Indian Education in Mexico." Prospects 20,3: 345-356.

Verhine, R.E. and A.M.P de Melo. 1988. "Causes of School Failure: The Case of the State of Bahia in Brazil." Prospects 18,4: 557-568.

World Bank. 1986. Brazil: Finance of Primary Education. A World Bank Country Study. Washington, D.C.: The World Bank.

Zuniga, M. 1990. "Educational Policies and Experiments among Indigenous Populations in Peru." Prospects 20,3: 365-376. 
Annex 1. Mean Sample Charneteriaties, Bollvia 1989

\begin{tabular}{llll}
\hline Variable & Mean & s.d. & $\mathbf{N}$ \\
\hline
\end{tabular}

Individual Characieristics

Repeater

Age

Years of Schooling

Male

Indian

Private School

Region (Departamento)

Chuquisaca

La Paz

Cochabamba

Oruro

Potosi

Tarija

Santa Cruz

Beni

Household Characteristics

Mother's Schooling

Father's Schooling

Family Income

Male Household Head

Siblings

Rooms (t)

Kitchen

Running Water

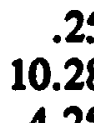

4.25

.51

.12

.22
.43

2.18

2.10

.50

.33

.42
6402

6402

640 ?

6402

6402

6402
.04

.38

.16

.10

.05

.02

.23

.03
.18

.48

.37

.30

.22

.15

.42

.17
6402

6402

6402

6402

6402

6402

6402

6402

Household Fead Occupation

Laborer

Employee

Self Employed

Employer

Other
7.33

8.54

675.75

.92

4.06

3.07

.79

.45
4.30

4.39

1196.13

.27

1.72

1.99

.41

.50
5616

5956

6402

6402

6402

6402

6402

6402
.14

.36

.33

.04

.12
.35

.48

.47

.20

.32
6402

6402

6402

6402

6402 
Annex 1 (Cont'd) Mean Sample Characteristics, Guatemala 1989

\begin{tabular}{llll}
\hline Variable & Mean & s.d. & $N$ \\
\hline
\end{tabular}

Individual Characteristics

Repeater

Age

Years of Schooling

Male

Indian

$\begin{array}{rrr}.71 & .45 & 2974 \\ 11.66 & 1.27 & 2974 \\ 3.22 & 1.54 & 2974 \\ .54 & .50 & 2974 \\ .29 & .46 & 2974 \\ .58 & .49 & 2974\end{array}$

Rural

Household Characteristics

Mother's Schooling

Father's Schooling

Family Income

Male Household Head

Siblings

Rooms (f)

Kitchen

Running Water

$\begin{array}{rrr}3.20 & 2.70 & 2974 \\ 3.55 & 2.70 & 2974 \\ 400.57 & 522.29 & 2974 \\ .86 & .34 & 2974 \\ 2.78 & 1.37 & 2974 \\ 2.91 & 1.47 & 2974 \\ .43 & .49 & 2974 \\ .53 & .50 & 2974\end{array}$

Household Head Occupation

Private Sector Employee

Public Sector Employee

Self Employed

Employer

$.17 \quad 2974$


Annex 2 Zero-order Correlation Matrix (Selected Variables)

\begin{tabular}{lrrr}
\hline Variable & SF & SM & YFAM \\
\hline Bolivia & & & \\
& & & \\
S & .063 & .080 & .056 \\
REPEAT & -.243 & -.231 & -.057 \\
SAGE & .215 & .230 & .061 \\
OVERAGE & -.202 & -.195 & -.053
\end{tabular}

\section{Guntemala}

S

REPEAT

SAGE OVERAGE

.429

$-.337$

.437

.392
.475

$-.393$

.504

.458
.249

$-.214$

.255

.227

Note: All correlation coefincients are ctatistically significant at the $1 \%$ probability level or better. 
Annex 3 Logistic Regression Results: The Determinants of Regultion in Bolivia (Dependent Variables REPLAT)

\begin{tabular}{|c|c|c|c|}
\hline Variable & $\begin{array}{l}\text { Logit } \\
\text { Coofficient }\end{array}$ & $\begin{array}{l}\text { Variable } \\
\text { Mean }\end{array}$ & $\begin{array}{l}\text { Mangianl } \\
\text { Efrox (\%) }\end{array}$ \\
\hline$A G E$ & $\begin{array}{l}0.354 \\
(20.3)\end{array}$ & 10.240 & 6.15 \\
\hline MALE & $\begin{array}{r}-0.07 i \\
(1.0)\end{array}$ & .508 & -1.23 \\
\hline INDIG & $\begin{array}{r}0.356 \\
(3.3)\end{array}$ & .101 & 6.21 \\
\hline Chuquisaca & $\begin{array}{r}0.701 \\
(2.9)\end{array}$ & .032 & -12.19 \\
\hline Cuchabamba & $\begin{array}{r}-0.603 \\
(5.3)\end{array}$ & .166 & -10.48 \\
\hline Orumo & $\begin{array}{r}-0.460 \\
(3.0)\end{array}$ & .099 & -8.00 \\
\hline Potasi & $\begin{array}{r}-0.265 \\
(1.5)\end{array}$ & .046 & -4.61 \\
\hline Tarija & $\begin{array}{r}-0.245 \\
(1.0)\end{array}$ & .024 & -4.26 \\
\hline Sansa Cruz & $\begin{array}{r}-0.352 \\
(3.6)\end{array}$ & .238 & -6.14 \\
\hline Beni & $\begin{array}{r}0.473 \\
(2.5)\end{array}$ & .032 & 8.24 \\
\hline PRIVATE & $\begin{array}{r}-0.661 \\
(5.4)\end{array}$ & .245 & -11.49 \\
\hline SM & $\begin{array}{r}-0.075 \\
(7.0)\end{array}$ & 7.328 & -1.32 \\
\hline YFAM(x1000) & $\begin{array}{r}0.009 \\
(0.3)\end{array}$ & .708 & .16 \\
\hline MALEHFD & $\begin{array}{r}-0.443 \\
(3.7)\end{array}$ & .913 & -7.72 \\
\hline \multicolumn{4}{|l|}{ QCCEIHD } \\
\hline LABORER & $\begin{array}{r}0.125 \\
(0.9)\end{array}$ & .138 & 2.17 \\
\hline EMPLOYEE & $\begin{array}{r}-0.355 \\
(3.0)\end{array}$ & .380 & -6.17 \\
\hline SELFEMPLOYED & $\begin{array}{r}-0.217 \\
(1.8)\end{array}$ & .323 & -3.77 \\
\hline EMPLOYER & $\begin{array}{r}-0.680 \\
(2.5)\end{array}$ & .042 & -11.82 \\
\hline NSIBS & $\begin{array}{r}0.104 \\
(4.9)\end{array}$ & 4.003 & 1.81 \\
\hline NROOMS & $\begin{array}{r}-0.132 \\
(5.5)\end{array}$ & 3.125 & -2.31 \\
\hline KITCHEN & $\begin{array}{r}-0.125 \\
(1.4)\end{array}$ & .796 & -2.17 \\
\hline RUNWATER & $\begin{array}{r}-0.293 \\
(3.7)\end{array}$ & .467 & -5.09 \\
\hline Constant & -3.425 & & \\
\hline $\begin{array}{l}\text { Chi-equare } \\
\mathbf{N}\end{array}$ & $\begin{array}{l}1058 \\
5614 \\
\end{array}$ & & \\
\hline
\end{tabular}

Note: Numbers in parentheces represent tovalues. 


\section{6}

Annex 3 (Cont'd) Logistic Regression Results: The Determinants of Repetition in Guatemala (Dependent Variable: REPEAT)

\begin{tabular}{|c|c|c|c|}
\hline Variable & $\begin{array}{c}\text { Logit } \\
\text { Coofficient }\end{array}$ & $\begin{array}{l}\text { Variable } \\
\text { Mean }\end{array}$ & $\begin{array}{c}\text { Marginal } \\
\text { Effect (\%) }\end{array}$ \\
\hline $\mathbf{A G E}$ & $\begin{array}{r}0.629 \\
(14.3)\end{array}$ & 11.660 & 1.1 .31 \\
\hline MALE & $\begin{array}{r}0.037 \\
(0.4)\end{array}$ & .538 & 0.84 \\
\hline NDIG & $\begin{array}{r}0.515 \\
(3.9)\end{array}$ & .295 & 11.72 \\
\hline RURAL & $\begin{array}{r}0.708 \\
(6.7)\end{array}$ & .577 & 16.11 \\
\hline $\mathbf{S M}$ & $\begin{array}{l}-0.293 \\
(12.3)\end{array}$ & 3.199 & -6.67 \\
\hline YFAM(x1000) & $\begin{array}{r}-0.186 \\
(1.8)\end{array}$ & .401 & -4.23 \\
\hline MALEHHD & $\begin{array}{r}0.304 \\
(2.0)\end{array}$ & .863 & 6.92 \\
\hline \multicolumn{4}{|l|}{ OCCHRD } \\
\hline PRIVATE SECTOR & $\begin{array}{r}0.074 \\
(0.4)\end{array}$ & .369 & 1.68 \\
\hline PUBLIC SECTOR & $\begin{array}{r}-0.412 \\
(2.0)\end{array}$ & .105 & -9.38 \\
\hline SELFEMPLOYED & $\begin{array}{r}0.017 \\
(0.1)\end{array}$ & .414 & 0.39 \\
\hline NSIBS & $\begin{array}{r}0.037 \\
(7.1)\end{array}$ & 2.782 & 0.84 \\
\hline NROOMS & $\begin{array}{r}-0.215 \\
(5.2)\end{array}$ & 2.912 & -4.89 \\
\hline KTCHEN & $\begin{array}{c}0.052 \\
(0.5)\end{array}$ & .429 & 1.18 \\
\hline RUNWATER & $\begin{array}{r}-0.335 \\
(3.1)\end{array}$ & .532 & -7.62 \\
\hline Constant & -5.859 & & \\
\hline $\begin{array}{l}\text { Chi-square } \\
\mathbf{N}\end{array}$ & $\begin{array}{r}971 \\
2974\end{array}$ & & \\
\hline
\end{tabular}

Note: Numbers in pareatheses represent t-values. 
Pollcy Research Working Paper Series

\section{Titie}

WPS1006 Preparing Multiyear Railway Investment Plans: A Market-Oriented Approach

\section{WPS1007 Global Estimates and Projections of Mortality by Cause, 1970-2015 \\ WPS1008 Do the Poor Insure? A Synthesis of the Literature on Risk and \\ Consumption in Developing Countries}

Rodolfo A. Bulatao

Patience W. Stephens

Harold Alderman

Christina H. Paxson

Jorge M. Rebelo
Author Date

Paul A. Higgins

Harold Alderman

A Study of Energy Expenditure,

Fertility, and Nutritional Status in Ghana

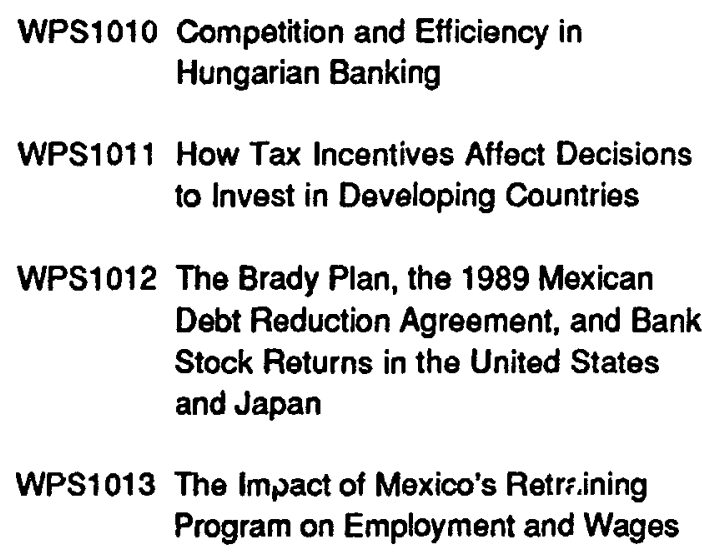

Dimitri Vittas

Craig Neal

Robin Boadway

Anwar Shah

Haluk Unal

Asli Demirgüç-Kunt

Kwok-Wai Loung

Ana Revenga

Michelle Riboud

Hong Tan

WPs1014 Ethnicity, Education, and Earnings

in Bolivia and Guatemala

WPS1015 Benefit Incidence Analysis in Developing Countries

George Psacharopoulos

Thomas M. Selden

Michael J. Wasylenko

My T. Vu

Eduard Bos

Ann Levin

Population Projections, 1992-93

Edition

WPS1017 Rural Poverty, Migration, and the Environment in Developing Countries: Three Case Studies

WPS1018 Tariff and Tax Reform: Do World Bank Recommendations Integrate Revenue and Protection Objectives?
Contact for paper

October 1992

A. Turner 30933

October 1992

O. Nadora 31091

October 1992

C. Spooner

32116

October 1992

C. Spooner 32116

October 1992

W. Pitayatonakarn 37664

November 1992

C. Jones

37754

November 1992

W. Patrawimolpon 37664

November 1992

D. Young 30932

November 1992

L. Longo 39244

November 1992

C. Jones

37754

November 1992

O. Nadora 31091

November 1992

WDR

31091

November 1992

P. Pender 37851 


\section{Pollcy Research Working Paper Serles}

\begin{tabular}{|c|c|c|c|c|}
\hline & Titlo & Author & Date & $\begin{array}{l}\text { Contact } \\
\text { for paper }\end{array}$ \\
\hline WPS1019 & $\begin{array}{l}\text { How Effective are Directed Credit } \\
\text { Policies in the United States? } \\
\text { A Literature Survey }\end{array}$ & Anita M. Schwarz & November 1992 & $\begin{array}{l}\text { M. Raggambi } \\
37664\end{array}$ \\
\hline WPS1020 & $\begin{array}{l}\text { Another Look at Population and } \\
\text { and Global Warming }\end{array}$ & Nancy Birdsall & November 1992 & $\begin{array}{l}\text { S. Rothschild } \\
37460\end{array}$ \\
\hline WPS1021 & $\begin{array}{l}\text { Measuring Welfare Changes from } \\
\text { Commodity Price Stabilization in } \\
\text { Small Open Economies }\end{array}$ & $\begin{array}{l}\text { Jonathan R. Coleman } \\
\text { Chris Jones }\end{array}$ & November 1992 & $\begin{array}{l}\text { D. Gustafson } \\
33714\end{array}$ \\
\hline WPS1022 & $\begin{array}{l}\text { A New Approach to Evaluating Trade } \\
\text { Policy }\end{array}$ & $\begin{array}{l}\text { James E. Anderson } \\
\text { J. Peter Neary }\end{array}$ & November 1992 & $\begin{array}{l}\text { M. T. Sanchez } \\
33731\end{array}$ \\
\hline WPS1023 & Tariff Index Theory & James E. Anderson & November 1992 & $\begin{array}{l}\text { M. T. Sanchez } \\
33731\end{array}$ \\
\hline WPS1024 & $\begin{array}{l}\text { An Exact Approach for Evaluating } \\
\text { the Benefits from Technological } \\
\text { Change }\end{array}$ & $\begin{array}{l}\text { Will Martin } \\
\text { Julian M. Alston }\end{array}$ & November 1992 & $\begin{array}{l}\text { D. Gustafson } \\
33714\end{array}$ \\
\hline WPS1025 & $\begin{array}{l}\text { Openness and Economic } \\
\text { Performance in Sub-Saharan Africa: } \\
\text { Evidence from Time-Series Cross- } \\
\text { Country Analysis }\end{array}$ & Kazi M. Matin & November 1992 & $\begin{array}{l}\text { D. Ballantyne } \\
38004\end{array}$ \\
\hline WPS1026 & $\begin{array}{l}\text { Financial Liberalization and } \\
\text { Adjustment in Chile and New Zealand }\end{array}$ & $\begin{array}{l}\text { Paul D. McNelis } \\
\text { Klaus Schmidt-Hebbel }\end{array}$ & November 1992 & $\begin{array}{l}\text { A. Marañon } \\
31450\end{array}$ \\
\hline WPS1027 L & $\begin{array}{l}\text { Lessons from Bank Privatization } \\
\text { in Mexico }\end{array}$ & Guillermo Barnes & November 1992 & $\begin{array}{l}\text { W. Pitayatonakarn } \\
37664\end{array}$ \\
\hline WPS1028 & $\begin{array}{l}\text { Socioeconomic and Ethnic } \\
\text { Determinants of Grade Repetition } \\
\text { in Bolivia and Guatemala }\end{array}$ & $\begin{array}{l}\text { Harry Anthony Patrinos } \\
\text { George Psacharopoulos }\end{array}$ & November 1992 & $\begin{array}{l}\text { L. Longo } \\
39244\end{array}$ \\
\hline
\end{tabular}

